\title{
Application of Electron Beam Melting to the Removal of Phosphorus from Silicon: Toward Production of Solar-Grade Silicon by Metallurgical Processes
}

\author{
Hideaki Sasaki, ${ }^{1}$ Yoshifumi Kobashi, ${ }^{2}$ Takashi Nagai, ${ }^{3}$ and Masafumi Maeda ${ }^{1}$ \\ ${ }^{1}$ International Research Center for Sustainable Materials, Institute of Industrial Science, the University of Tokyo, \\ 4-6-1 Komaba, Meguro-ku, Tokyo 153-8505, Japan \\ ${ }^{2}$ Department of Materials Engineering, Graduate School of Engineering, the University of Tokyo, 7-3-1 Hongo, \\ Bunkyo-ku, Tokyo 113-8656, Japan \\ ${ }^{3}$ Department of Mechanical Science and Engineering, Chiba Institute of Technology, 2-17-1 Tsudanuma, \\ Narashino, Chiba 275-0016, Japan \\ Correspondence should be addressed to Hideaki Sasaki; hideakis@iis.u-tokyo.ac.jp
}

Received 28 June 2013; Accepted 16 September 2013

Academic Editor: Raghubir Singh Anand

Copyright (C) 2013 Hideaki Sasaki et al. This is an open access article distributed under the Creative Commons Attribution License, which permits unrestricted use, distribution, and reproduction in any medium, provided the original work is properly cited.

\begin{abstract}
Removal methods of impurity from metallurgical-grade silicon ( $\mathrm{Si}$ ) are intensively studied to produce solar-grade silicon (SoG-Si) with a smaller economical load and lower cost. Removal of phosphorus (P) has been an important issue because of difficulties in application of conventional metallurgical methods such as solidification refining. Because P evaporates preferentially from molten $\mathrm{Si}$ due to its high vapor pressure, electron beam (EB) melting has been applied to the purification of Si. The evaporation of impurity $\mathrm{P}$ from $\mathrm{Si}$ is considered based on previous thermodynamic investigations here, and several research reports on EB melting of Si are reviewed.
\end{abstract}

\section{Application of EB Melting to Removal of P from Si}

Photovoltaic power generation is drawing attention, and the most prevalent material for solar cells is silicon (Si). Monocrystalline, polycrystalline, and amorphous $\mathrm{Si}$ accounted for $90 \%$ of total solar cell production in 2011 [1]. Conversion efficiency of solar cells depends on the purity of Si [2], and it is generally believed that a purity of 99.9999\% is required for solar grade silicon (SoG-Si). The Siemens process, which is used to produce semiconductor grade silicon (99.999999999\%), has been applied to SoG$\mathrm{Si}$; however, the process consumes a large amount of energy because it includes chlorination, distillation, and reduction of $\mathrm{Si}$. Therefore, a less expensive purification method of $\mathrm{Si}$ is required for widespread use of solar cells.

To decrease the energy consumed in the production of SoG-Si, methods of removing impurities from metallurgical grade $\mathrm{Si}$ (MG-Si, $99 \%$ ) have been developed. These methods include, for example, directional solidifications making use of different solubility of impurity elements into solid and liquid Si. These methods are referred to as "metallurgical processes" to distinguish them from "chemical processes" such as the Siemens process. Table 1 shows examples of acceptable concentrations of impurities in SoG-Si. In one case, the values were defined as the impurity concentration which degrades the conversion efficiency of a solar cell by $10 \%$ [3]. Acceptable concentrations were defined more strictly elsewhere [4]. Table 1 also shows the segregation coefficient, which is the ratio of solubility of the element in solid $\mathrm{Si}$ and liquid Si at the melting point [5]. Elements with small segregation coefficients, such as $\mathrm{Fe}$ and $\mathrm{Ti}$, can be removed from Si by directional solidification. Phosphorus (P) and boron (B), however, are difficult to remove by this means because of their large segregation coefficient. Therefore, new processes have been intensively studied to remove these 
TABLE 1: Acceptable contents of impurity in SoG-Si $\left(C_{\mathrm{SoG}-\mathrm{Si}}\right)$ and their equilibrium segregation coefficients $(k)$.

\begin{tabular}{lccccccccc}
\hline Element & $\mathrm{Fe}$ & $\mathrm{Al}$ & $\mathrm{Cu}$ & $\mathrm{Ti}$ & $\mathrm{Ca}$ & $\mathrm{C}$ & $\mathrm{O}$ & $\mathrm{P}$ & $\mathrm{B}$ \\
\hline $\begin{array}{l}\text { Acceptable content, } C_{\text {SoG-Si }} \\
\text { (ppmw) [3] }\end{array}$ & $<1$ & $0.005-0.05$ & - & $<1$ & $<-2$ & $0.5-1$ & $10-20$ & $0.02-2$ & $0.1-10$ \\
$\begin{array}{l}\text { Acceptable content, } C_{\text {SoG-Si }} \\
\text { (ppmw) [4] }\end{array}$ & $<0.007$ & $<0.06$ & - & $<4 \times 10^{-5}$ & - & $<3$ & $<4$ & $<0.1$ & $0.1-0.3$ \\
Segregation coefficient, $k$ & $8 \times 10^{-6}$ & $2 \times 10^{-3}$ & $4 \times 10^{-4}$ & $3.6 \times 10^{-6}$ & - & $0.034-0.3[3]$ & $0.2-1.25[3]$ & 0.35 & $0.72-0.8$ \\
\hline
\end{tabular}

elements. The removal of $\mathrm{P}$ and $\mathrm{B}$ from $\mathrm{Si}$ is also a key problem in the recycling of $\mathrm{Si}$ from waste products because they are generally used as dopants.

Although removal of a low level of $\mathrm{P}$ was previously believed to be impossible, one of the authors (Maeda) applied electron beam (EB) melting under $10^{-2} \mathrm{~Pa}$ and demonstrated that removal could be successful [6]. This research showed that the evaporation of $\mathrm{P}$ can be promoted by melting under high vacuum. EB melting also has the following additional advantages. (i) Contamination from the atmosphere is prevented. (ii) Contamination from a crucible is also prevented by using a water-cooled copper crucible, with which the bottom part of Si does not melt. (iii) Localized heating by EB generates a convective flow in molten $\mathrm{Si}$, which enhances the removal of $P$.

Figures 1(a)-1(c) show previously proposed processes to produce SoG-Si from MG-Si [7-9]. These included the vacuum refining to remove $\mathrm{P}$ and other elements with high vapor pressure. On the other hand, previous research employed an oxidative removal of boron by applying a steam-added plasma melting method $[10,11]$. The proposed processes still require an improvement, and thus techniques for removing $\mathrm{B}$ are under intensive investigation. To produce SoG-Si at the lowest possible cost, however, an innovative and simpler process will be needed as Figure 1(d) shows.

\section{Considerations on the Evaporation of $\mathbf{P}$ from Molten Si Based on Thermodynamics}

For effective removal of $\mathrm{P}$ from molten $\mathrm{Si}$, it is necessary to understand the mechanism of its preferential evaporation. In this section, the evaporation is discussed based on thermodynamic information on the reaction and then its kinetics is considered.

\subsection{Evaporation of P from Molten Si Estimated from Thermo-} dynamic Measurement. Phosphorus evaporates in the forms of $\mathrm{P}_{4}(\mathrm{~g}), \mathrm{P}_{2}(\mathrm{~g})$, and $\mathrm{P}(\mathrm{g})$ and Gibbs energies of formation of the gas species have been reported [12]. Figure 2 shows predominant gaseous species (i.e., species having the highest vapor pressure) at various temperatures. The vertical axis is the thermodynamic activity of $\mathrm{P}$ with reference to red phosphorus. Pure $\mathrm{P}$ evaporates at relatively low temperatures mainly as $\mathrm{P}_{4}(\mathrm{~g})$, and the boiling point of white phosphorus is $552 \mathrm{~K}$. Figure 2 also shows that evaporation of $\mathrm{P}_{2}(\mathrm{~g})$ or $\mathrm{P}(\mathrm{g})$ becomes more dominant when the activity of $\mathrm{P}$ is lower and the temperature is higher. Therefore, in the removal of impurity $\mathrm{P}$ from molten $\mathrm{Si}$, evaporations of $\mathrm{P}_{2}$ (g) and $\mathrm{P}$ (g) are important. These reactions have been investigated by performing thermodynamic measurements on Si-P alloys equilibrated with $\mathrm{P}$ in the gas phase [13-15]. Miki et al. expressed the standard Gibbs energy changes for monoatomic and diatomic evaporations of $\mathrm{P}$ the following, respectively [13]:

$$
\begin{gathered}
\mathrm{P}(\mathrm{g})=\underline{\mathrm{P}}(\text { mass pct, in } \mathrm{Si}), \\
\Delta G_{1}^{\circ}=-387,000+103 T(\mathrm{~J} / \mathrm{mol}), \\
\frac{1}{2} \mathrm{P}_{2}(\mathrm{~g})=\underline{\mathrm{P}}(\text { mass pct, in } \mathrm{Si}), \\
\Delta G_{2}^{\circ}=-139,000+43.4 T(\mathrm{~J} / \mathrm{mol}) .
\end{gathered}
$$

Figure 3 shows vapor pressure of $\mathrm{P}(\mathrm{g})$ and $\mathrm{P}_{2}(\mathrm{~g})\left(p_{\mathrm{P}}\right.$ and $p_{\mathrm{P}_{2}}$, resp.) at 1800 and $2000 \mathrm{~K}$ calculated by the previous equations. Evaporation of $\mathrm{P}(\mathrm{g})$ is more dominant than $\mathrm{P}_{2}(\mathrm{~g})$ when $\mathrm{P}$ content in $\mathrm{Si}$ is lower. Raising temperature also causes the evaporation of $\mathrm{P}$ to become dominant. Vapor pressure of $\mathrm{Si}(\mathrm{g}), p_{\mathrm{Si}}$, was calculated by (3) [16] and is shown in Figure 3:

$$
\begin{gathered}
\operatorname{Si}(\mathrm{g})=\operatorname{Si}(\mathrm{l}) \\
\log p_{\mathrm{Si}}=-20900 \times\left(\frac{1}{T}\right)-0.565 \times \log T+12.9 .
\end{gathered}
$$

2.2. Evaporation Rate of $P$ from Molten Si and Evaporation Coefficient. When impurity $\mathrm{P}$ evaporates from molten $\mathrm{Si}$, the following steps might determine the rate of the entire reaction $[17,18]$ :

(i) transport of $\mathrm{P}$ atoms in the molten $\mathrm{Si}$ to liquid/gas surface,

(ii) formation of $\mathrm{P}$ atoms adsorbed on the liquid surface,

(iii) formation of $\mathrm{P}_{2}$ molecules from the $\mathrm{P}$ atoms on the surface,

(iv) evaporation of the adsorbed $\mathrm{P}$ atoms or $\mathrm{P}_{2}$ molecules,

(v) transport of the $\mathrm{P}(\mathrm{g})$ or $\mathrm{P}_{2}(\mathrm{~g})$ through the gas phase away from the liquid/gas surface.

Because EB melting generates a convective flow in molten $\mathrm{Si}$, step (i) is not believed to determine the reaction rate, especially when a small amount of $\mathrm{Si}$ is melted. Kemmotsu et al. examined the $\mathrm{P}$ removal from molten Si stirred by injecting Ar gas and confirmed that the stirring did not enhance the removal [19]. Step (v) is also assumed to be ignorable because $\mathrm{P}$ evaporates under high vacuum. Experimental results by Miyake and his colleagues showed that removal rate of $\mathrm{P}$ 


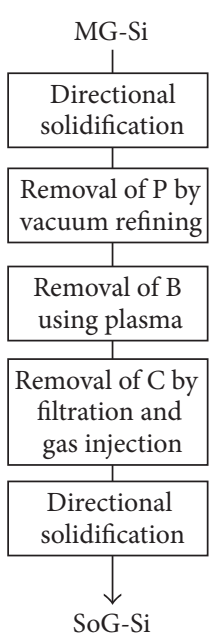

(a) Yuge et al. (1994) [7].

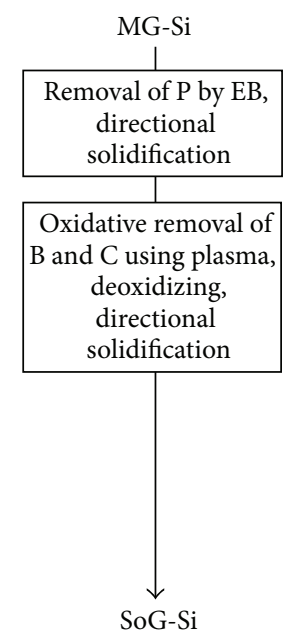

(b) Kato et al. (2000)

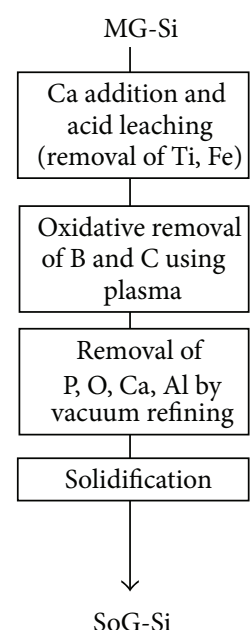

(c) Morita and Miki (2003) [9].

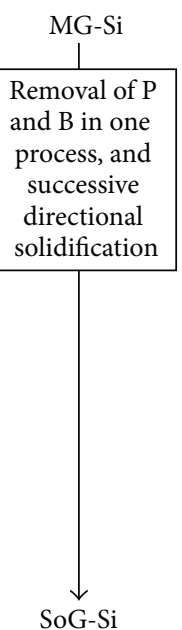

(d) Desired
innovative
process.

FIGURE 1: Proposed refining processes to purify MG-Si to SoG-Si.

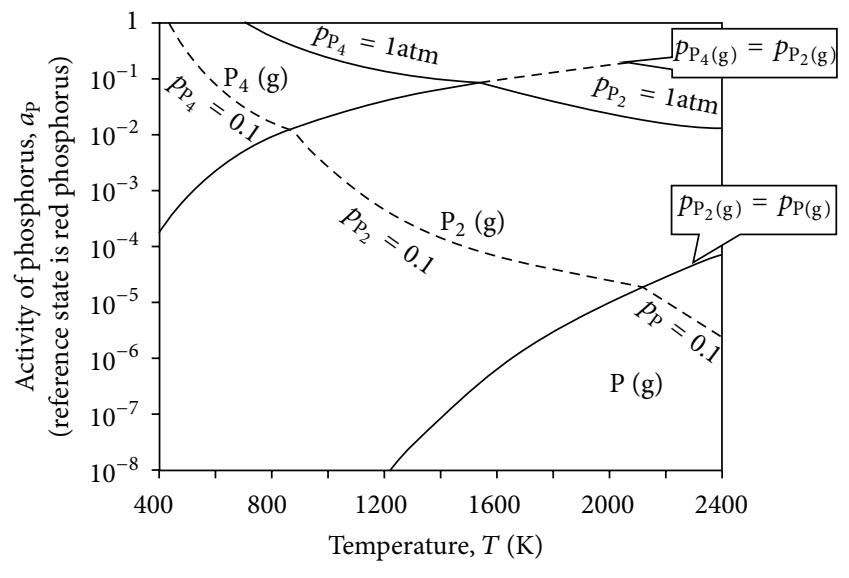

FIGURE 2: Estimation of predominant gaseous species in equilibrium [12]. Reference state of phosphorus activity is red phosphorus.

under low vacuum (higher than $1 \mathrm{~Pa}$ ) was similar to that under higher vacuum, suggesting there was no influence of the pressure in this range [20]. Therefore, steps (ii) (iv) are the most likely rate-determining steps. The rate of evaporation might be expressed by the Hertz-KnudsenLangmuir equation [21]:

$$
J_{i}=\beta p_{i} \sqrt{\frac{M_{i}}{2 \pi R T}},
$$

where $J_{i}\left(\mathrm{~kg} / \mathrm{m}_{2} \cdot \mathrm{s}\right)$ is the evaporation rate of chemical species $i, p_{i}(\mathrm{~Pa})$ is equilibrium vapor pressure, $M_{i}(\mathrm{~kg} / \mathrm{mol})$ is molar mass, and $R$ is gas constant. $\beta$ is a coefficient assumed to be unity here.

Figure 4(a) shows evaporation rate of $\mathrm{P}$ and Si calculated by (4) using $p$ determined by (1), (2), and (3). As discussed by others [13], the content of $\mathrm{P}$ in Si decreases when a ratio of

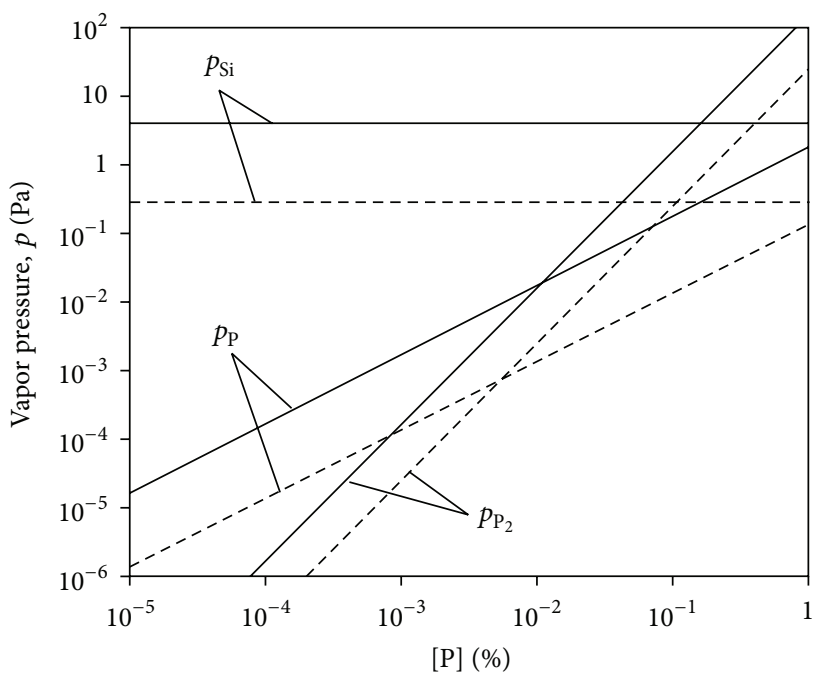

FIgURE 3: Equilibrium vapor pressure of impurity $\mathrm{P}$ and $\mathrm{Si}$ at $1800 \mathrm{~K}$ (broken line) and $2000 \mathrm{~K}$ (solid line).

the evaporation rate of $\mathrm{P}$ to that of $\mathrm{Si}$ is larger than the weight concentration of $\mathrm{P}$ in molten $\mathrm{Si}$ (see (5)):

$$
\frac{J_{\mathrm{P}}+J_{\mathrm{P}_{2}}}{J_{\mathrm{Si}}}>\frac{[\mathrm{P}]}{100} \text {. }
$$

Using (5), an evaporation coefficient, $\alpha$, is defined by the following as an index of purification:

$$
\alpha=\frac{J_{\mathrm{P}}+J_{\mathrm{P}_{2}}}{J_{\mathrm{Si}}} \frac{100}{[\mathrm{P}]} .
$$

When $\alpha$ is larger than $1, \mathrm{P}$ content in molten Si decreases during melting. As plotted in Figure 4(b), $\alpha$ becomes almost constant for smaller $[\mathrm{P}]$ because the evaporation of $\mathrm{P}_{2}$ is less 


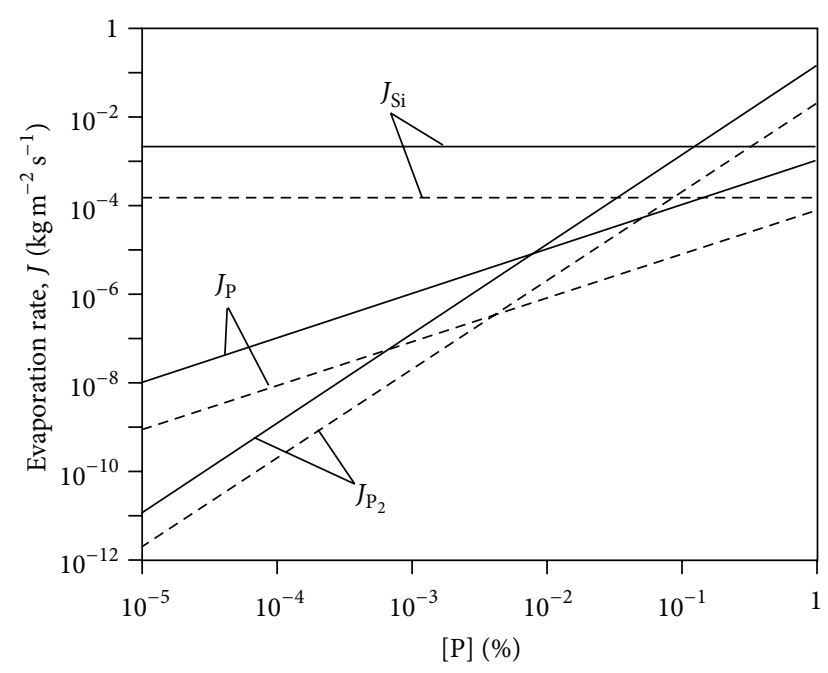

(a)

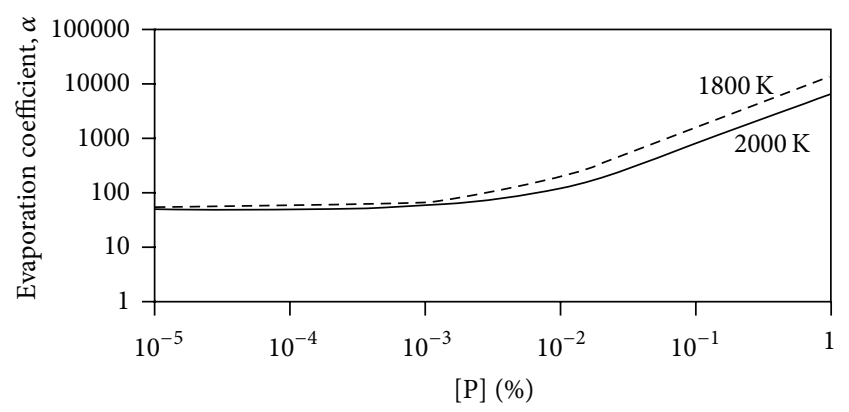

(b)

Figure 4: (a) Evaporation rate of $\mathrm{P}$ and Si from molten Si at 1800 (broken line) and $2000 \mathrm{~K}$ (solid line). (b) Evaporation coefficient.

significant. If the evaporation of $\mathrm{P}_{2}$ is ignored, $\alpha$ is expressed by the following which was derived from (4) and (6):

$$
\alpha=\frac{100 p_{[\mathrm{P}]=1} \sqrt{M_{\mathrm{P}}}}{p_{\mathrm{Si}}^{\circ} \sqrt{M_{\mathrm{Si}}}},
$$

where $p_{[\mathrm{P}]=1}$ is vapor pressure of $\mathrm{P}(\mathrm{g})$ equilibrated with $\mathrm{P}$ in $\mathrm{Si}$ at $[\mathrm{P}]=1 \mathrm{wt} \%$.

\subsection{Estimated Weight of Si and $P$ during Melting. Because} energy cost and yield are important in the production of SoG$\mathrm{Si}$, the evaporation of Si during EB melting should not be ignored. The change of Si weight and P content during the melting is estimated based on (4). Purification of Si of $W_{\mathrm{Si}}(\mathrm{kg})$ containing $\mathrm{P}$ of $W_{\mathrm{P}}(\mathrm{kg})$ is considered. The weight percentage of $\mathrm{P}$ in $\mathrm{Si},[\mathrm{P}]$, is expressed as follows:

$$
[\mathrm{P}]=100 \times \frac{W_{\mathrm{P}}}{W_{\mathrm{Si}}} .
$$

Surface area of molten $\mathrm{Si}$ is assumed to be constant at $A$ $\left(\mathrm{m}^{2}\right)$, and evaporations of $\mathrm{Si}$ and monoatomic $\mathrm{P}$ are taken into account. The evaporation rate of $\mathrm{P}$ is expressed as follows:

$$
J_{\mathrm{P}}=p_{[\mathrm{P}]=1} \sqrt{\frac{M}{2 \pi R T}} \times[\mathrm{P}] .
$$

By defining $a=p_{[\mathrm{P}]=1} \sqrt{M / 2 \pi R T}$, the temporal change in $W_{\mathrm{P}}$ is expressed as follows:

$$
\frac{d W_{\mathrm{P}}}{d t}=-A J_{\mathrm{P}}=-A a[\mathrm{P}]
$$

An evaporation rate of $\mathrm{Si}$ is expressed as follows:

$$
\frac{d W_{\mathrm{Si}}}{d t}=-A J_{\mathrm{Si}}=A b,
$$

where $b=p_{\mathrm{Si}} \sqrt{M_{\mathrm{Si}} / 2 \pi R T}$ from (4). From (10) and (11), $W_{\mathrm{Si}}$ and $W_{\mathrm{P}}$ are expressed by (12) and (13) as functions of time using the initial weight, $W_{\mathrm{P}}^{\circ}$ and $W_{\mathrm{Si}}^{\circ}$ :

$$
\begin{gathered}
W_{\mathrm{P}}=W_{\mathrm{P}}^{\circ}\left(1-\frac{A b t}{W_{\mathrm{Si}}^{\circ}}\right)^{100 a / b}, \\
W_{\mathrm{Si}}=W_{\mathrm{Si}}^{\circ}-A b t .
\end{gathered}
$$

Figure 5 shows changes in $W_{\mathrm{P}}$ and $W_{\mathrm{Si}}$ at 1800 and $2000 \mathrm{~K}$, calculated by (12) and (13) assuming $W_{\mathrm{P}}^{\circ}=0.0000025, W_{\mathrm{Si}}^{\circ}=$ 0.25 , and $A=10^{-2} \mathrm{~m}^{2}$. Initially, [P] is 0.001 , and its change is also plotted below. Looking at the time required for purification, smelting at higher temperature is advantageous.

\section{Reported Research and Rate Constants}

Previous research findings on the removal of $\mathrm{P}$ by EB melting are listed in Table 2. Ikeda and Maeda [6] investigated the effect of the EB power and surface temperatures of molten $\mathrm{Si}$ on the removal rate of impurities. Miyake et al. [20] melted P-doped Si under a low vacuum (5-7 Pa) and found little influence of the pressure on the removal rate. Hanazawa et al. $[22,23]$ reported that the content of $\mathrm{P}$ decreased to $0.1 \mathrm{ppm}$, which is below the acceptable content for SoG-Si. More recently, large-scale demonstration, numerical simulation, and optimization of melting techniques have been reported. Table 3 shows that research on P removal from molten Si not by EB melting but by induction furnaces.

In some research, experimental results on $\mathrm{P}$ removal were assessed by estimating the apparent mass transfer coefficient. When a first-order reaction is assumed, the coefficient, $k_{1}$, is defined as follows:

$$
-\frac{d[\mathrm{P}]}{d t}=k_{1} \frac{A}{V}[\mathrm{P}] .
$$

If the evaporation is the rate-determining step, the following is derived from (4):

$$
k_{1}=\frac{100}{\rho_{\mathrm{Si}}} \sqrt{\frac{M_{\mathrm{P}}}{2 \pi R T}} \exp \frac{\Delta G_{1}^{\circ}}{R T} .
$$

A mass transfer coefficient assumed, a second-order reaction (i.e., evaporation of $\mathrm{P}_{2}$ ) is defined as $k_{2}$ in the following:

$$
-\frac{d[\mathrm{P}]}{d t}=k_{2} \frac{A}{V}[\mathrm{P}]^{2} .
$$

Miki et al. [13] estimated the time variation of $\mathrm{P}$ content in Si using $k_{1}$ and $k_{2}$ derived from (1), (2), and (4). Previous 

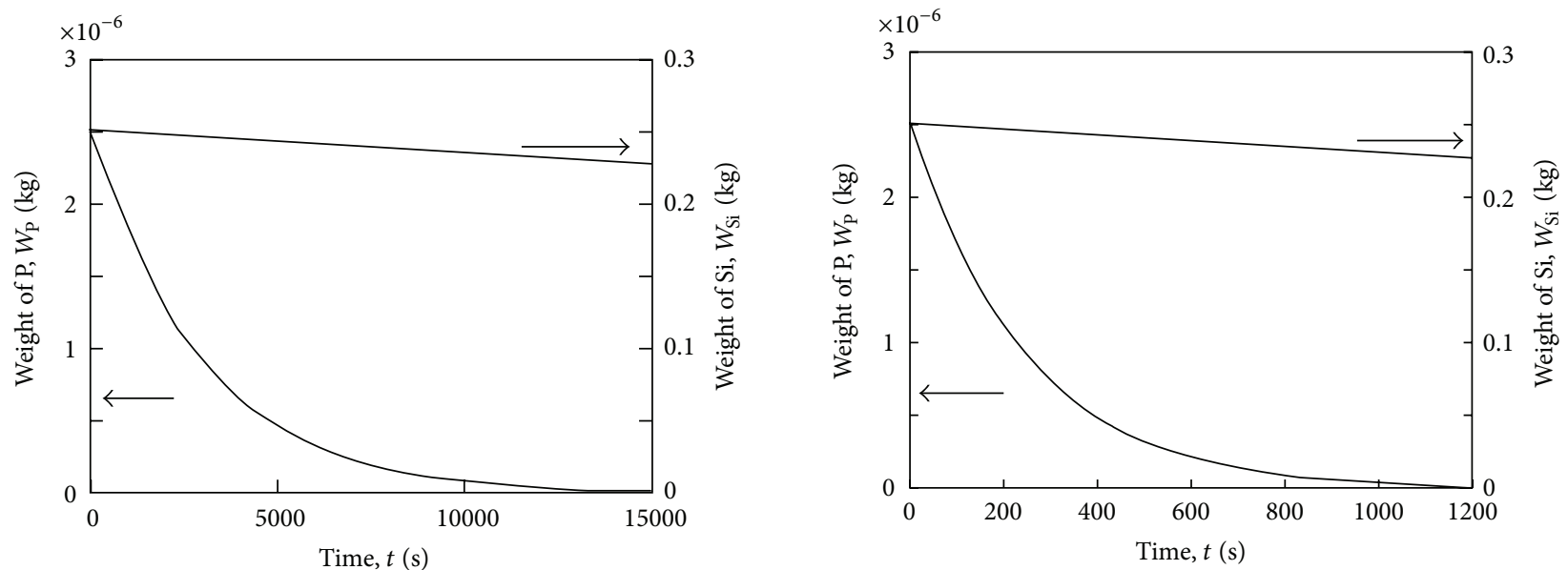

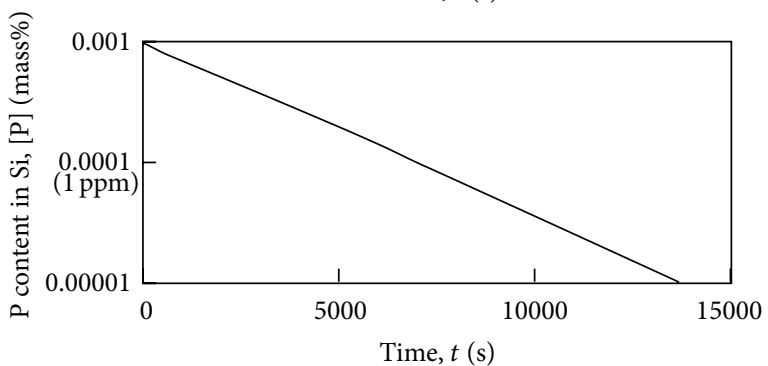

(a)

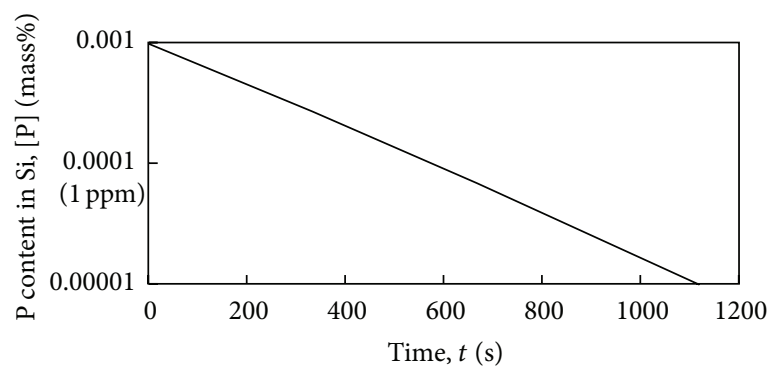

(b)

FIGURE 5: Estimated changes in $W_{\mathrm{P}}$ and $W_{\mathrm{Si}}$ during melting at (a) 1800 and (b) $2000 \mathrm{~K}$.

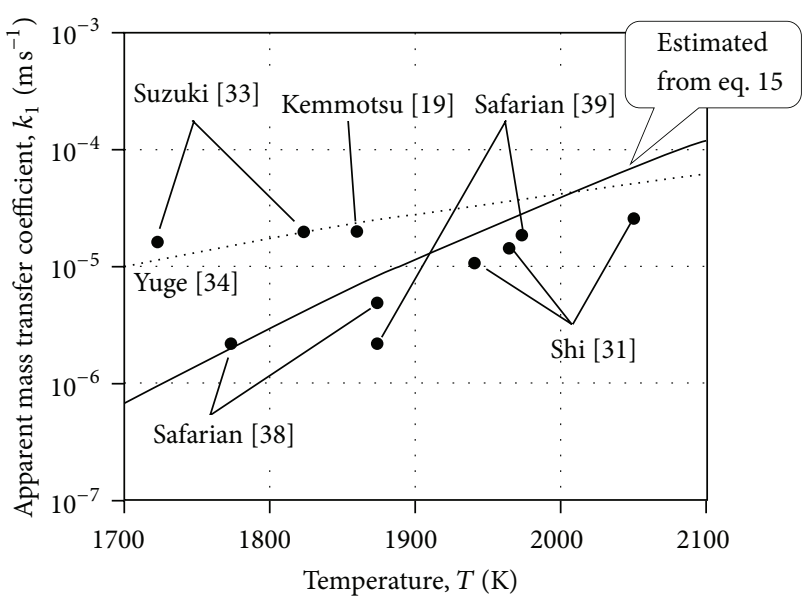

Figure 6: Apparent mass transfer coefficient of $\mathrm{P}$ removal from molten $\mathrm{Si}$.

research discussed their experimental results assuming firstorder reaction and reported values of $k_{1}$ as shown in Tables 2 and 3. Although there are differences between reported values, $k_{1}$ is roughly in agreement. These values are plotted in Figure 6 with the estimated values from (15). Some experiments obtained $k_{1}$ higher than the estimated line below $1900 \mathrm{~K}$. One possible reason is that $\mathrm{P}$ evaporates in forms of $\mathrm{P}$ and $\mathrm{P}_{2}$. Temperature inhomogeneity of molten $\mathrm{Si}$ also might have caused the deviation; that is, local temperature of Si surface might be higher than estimated because of localized heating with $\mathrm{EB}$, and $\mathrm{P}$ might have evaporated there preferentially. In addition, because $\mathrm{P}$ is a surface-active element, it is assumed to concentrate on the surface of molten $\mathrm{Si}$ [40]. This effect is believed to enhance its evaporation, although previous research has discussed this only minimally. Deviations at higher temperatures might be caused by mass transport of P in molten Si or gas phase. Shi et al. [31] and Zheng et al. [36] discussed their results by considering an overall mass transfer coefficient, which was a combination of the reaction step and the mass transport.

\section{Additional Availability of EB Melting}

As previously reported, EB melting of Si can remove not only $\mathrm{P}$ but also other impurities which have high vapor pressures. The authors' group reported removal of $\mathrm{Ca}, \mathrm{Al}$ [6], and $\mathrm{Sb}$ [20] from molten Si during EB melting. More recent studies confirmed removals of not only these impurities but also other elements [29, 41-43]. Among impurities, however, C and $\mathrm{B}$ were not removed by the melting because of low vapor pressure. On the other hand, the element might be removed by oxidizing (Figure 1) similar to decarburization in steel making. Therefore, plasma melting [11] and slag refining [4446] are under development for B removal from Si. After the oxidizing treatment, oxygen in $\mathrm{Si}$ is easily removed by $\mathrm{EB}$ melting because of the high vapor pressure of $\mathrm{SiO}(\mathrm{g})$.

In addition to the processes mentioned previously, various methods have been developed to remove impurities 


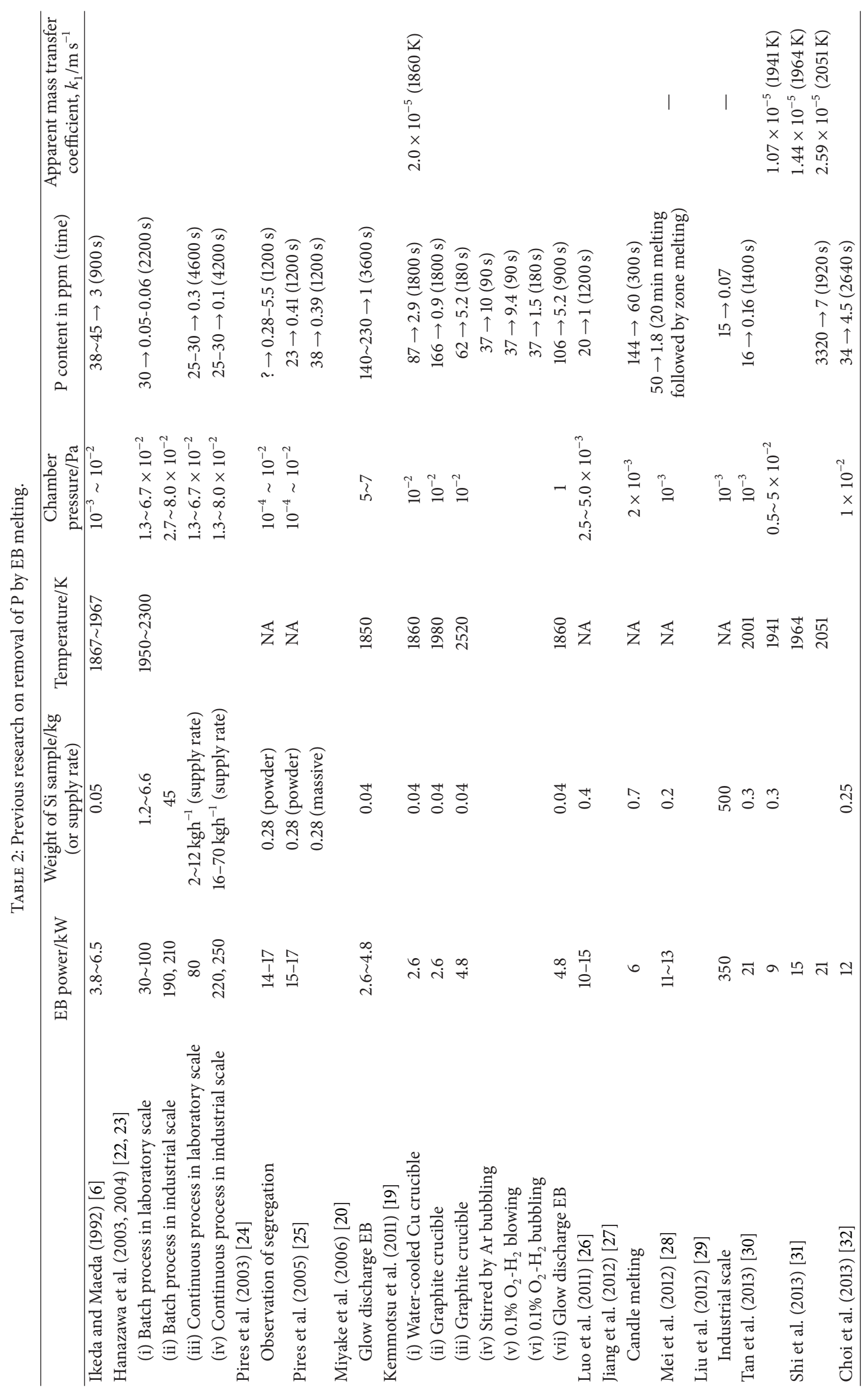


TABLE 3: Previous research on removal of $\mathrm{P}$ by induction furnace.

\begin{tabular}{|c|c|c|c|c|c|}
\hline & $\begin{array}{l}\text { Weight of Si } \\
\text { sample/kg }\end{array}$ & Temperature/K & $\begin{array}{c}\text { Chamber } \\
\text { pressure/Pa }\end{array}$ & $\begin{array}{l}\text { P content in ppm } \\
\text { (time) }\end{array}$ & $\begin{array}{c}\text { Apparent mass transfer } \\
\text { coefficient, } \\
k_{1} / \mathrm{m} \mathrm{s}^{-1}\end{array}$ \\
\hline \multirow{2}{*}{ Suzuki et al. (1990) [33] } & \multirow{2}{*}{0.02} & \multirow{2}{*}{$1723 \sim 1823$} & \multirow{2}{*}{$2.7 \times 10^{-2}$} & \multirow{2}{*}{$32 \rightarrow 6 \sim 7(2700 s)$} & $1.6 \times 10^{-5}(1723 \mathrm{~K})$ \\
\hline & & & & & $2.0 \times 10^{-5}(1823 \mathrm{~K})$ \\
\hline Yuge et al. (1997) [34] & $0.02,0.04,1$ & $1722 \sim 1915$ & $0.8 \sim 3.6 \times 10^{-2}$ & $7 \rightarrow<0.1(7200 \mathrm{~s})$ & $\ln k_{1}=-2.29-15600 / T$ \\
\hline \multirow{7}{*}{$\begin{array}{l}\text { Zheng et al. (2010) [35] } \\
(2011)[36,37]\end{array}$} & 5 & 1823 & 0.03 & $15 \rightarrow 11(7200 \mathrm{~s})$ & \multirow{7}{*}{$\begin{array}{l}\text { (Dependence on } \\
\text { pressure was studied) } \\
10^{-5} \sim 10^{-6} \text { at } 0.01 \sim 1 \mathrm{~Pa} \text {, } \\
\text { Below } 10^{-9} \text { at over } \\
10000 \mathrm{~Pa}(1783 \mathrm{~K})\end{array}$} \\
\hline & & 1873 & $0.03 \sim 0.07$ & $15 \rightarrow 7.3(7200 \mathrm{~s})$ & \\
\hline & & 1923 & $0.03 \sim 0.13$ & $15 \rightarrow 2.6(7200 \mathrm{~s})$ & \\
\hline & & 1923 & $0.02 \sim 0.09$ & $15 \rightarrow 1.7(7200 \mathrm{~s})$ & \\
\hline & & 1973 & $0.04 \sim 0.25$ & $15 \rightarrow 0.41(7200 \mathrm{~s})$ & \\
\hline & & 1973 & $0.01 \sim 0.05$ & $15 \rightarrow 0.15(7200 \mathrm{~s})$ & \\
\hline & - & 1873 & $0.6-0.8$ & $460 \rightarrow 10(3600 \mathrm{~s})$ & \\
\hline \multirow{4}{*}{$\begin{array}{l}\text { Safarian and Tangstad } \\
(2012)[38,39]\end{array}$} & \multirow{4}{*}{0.3} & 1773 & \multirow{4}{*}{0.5} & $17 \rightarrow 9.8(900 \mathrm{~s})$ & $2.3 \times 10^{-6}(1773 \mathrm{~K})$ \\
\hline & & 1873 & & $17 \rightarrow 5.9(900 \mathrm{~s}), 1.5(1800 \mathrm{~s})$ & $4.9 \times 10^{-6}(1873 \mathrm{~K})$ \\
\hline & & 1873 & & $24 \rightarrow 19(3600 \mathrm{~s})$ & $2.2 \times 10^{-6}(1873 \mathrm{~K})$ \\
\hline & & 1973 & & $24 \rightarrow 0.4 \sim 3(9000 \mathrm{~s})$ & $1.9 \times 10^{-5}(1973 \mathrm{~K})$ \\
\hline
\end{tabular}

in Si: for example, solidification using solvent metals and acid leaching [47]. To achieve production of SoG-Si by an economic process with low energy consumption, it will be necessary to bring together a great amount of expertise in the metallurgical technologies which have been developed for various metals.

\section{Conclusion}

EB techniques applied to removal of $\mathrm{P}$ from Si were reviewed. EB melting is believed to play an important role in the refining of Si because of its unique heating characteristics. It is necessary to integrate the scientific knowledge based on thermodynamic discussion and metallurgical technologies which have been developed for various metals toward an economical and environmentally friendly refining process for SoG-Si.

\section{References}

[1] PV NEWS, 31, 2012.

[2] R. H. Hopkins and A. Rohatgi, "Impurity effects in silicon for high efficiency solar cells," Journal of Crystal Growth, vol. 75, no. 1, pp. 67-79, 1986.

[3] M. A. Martorano, J. B. Ferreira Neto, T. S. Oliveira, and T. O. Tsubaki, "Refining of metallurgical silicon by directional solidification," Materials Science and Engineering B, vol. 176, no. 3, pp. 217-226, 2011.

[4] Y. Kato, N. Yuge, S. Hiwasa, H. Terashima, and F. Aratani, "New approach for refining process to solar grade silicon feedstock from metallurgical grade," Materia Japan, vol. 41, no. 1, pp. 5456, 2002.

[5] F. A. Trumbore, "Solid solubilities of impurity elements in germanium and silicon," The Bell System Technical Journal, vol. 30, pp. 205-233, 1960.
[6] T. Ikeda and M. Maeda, "Purification of metallurgical silicon for solar-grade silicon by electron beam button melting," ISIJ International, vol. 32, no. 5, pp. 635-642, 1992.

[7] N. Yuge, H. Baba, Y. Sakaguchi, K. Nishikawa, H. Terashima, and F. Aratani, "Purification of metallurgical silicon up to solar grade," Solar Energy Materials and Solar Cells, vol. 34, no. 1-4, pp. 243-250, 1994.

[8] Y. Kato, K. Hanazawa, H. Baba et al., "Purification of metallurgical grade silicon to solar grade for use in solar cell wafers," Tetsu-To-Hagane, vol. 86, no. 11, pp. 717-724, 2000.

[9] K. Morita and T. Miki, "Thermodynamics of solar-grade-silicon refining," Intermetallics, vol. 11, no. 11-12, pp. 1111-1117, 2003.

[10] T. Ikeda and M. Maeda, "Elimination of boron in molten silicon by reactive rotating plasma arc melting," Materials Transactions, vol. 37, no. 5, pp. 983-987, 1996.

[11] N. Nakamura, H. Baba, Y. Sakaguchi, and Y. Kato, "Boron removal in molten silicon by a steam-added plasma melting method," Materials Transactions, vol. 45, no. 3, pp. 858-864, 2004.

[12] M. E. Schlesinger, "The thermodynamic properties of phosphorus and solid binary phosphides," Chemical Reviews, vol. 102, no. 11, pp. 4267-4301, 2002.

[13] T. Miki, K. Morita, and N. Sano, "Thermodynamics of phosphorus in molten silicon," Metallurgical and Materials Transactions $B$, vol. 27, no. 6, pp. 937-941, 1996.

[14] A. I. Zaitsev, A. D. Litvina, and N. E. Shelkova, "Thermodynamic properties of Si-P melts," High Temperature, vol. 39, no. 2, pp. 227-232, 2001.

[15] T. Nagai, H. Sasaki, and M. Maeda, "Thermodynamic study for removal of phosphorus from molten silicon," T.T. Chen Honorary Symposium on Hydrometallurgy, Electrometallurgy and Materials Characterization, pp. 431-435, 2012.

[16] O. Kubaschewski and C. B. Alcock, Metallurgical Thermochemistry, Pergamon Press, Oxford, UK, 5th edition, 1979.

[17] R. G. Ward, "Evaporative losses during vacuum induction melting of steel," Journal of the Iron and Steel Institute, vol. 201, pp. 11-15, 1963. 
[18] R. Harris and W. G. Davenport, "Vacuum distillation of liquid metals: part I. Theory and experimental study," Metallurgical Transactions B, vol. 13, no. 4, pp. 581-588, 1982.

[19] T. Kemmotsu, T. Nagai, and M. Maeda, "Removal rate of phosphorus from molten silicon," High Temperature Materials and Processes, vol. 30, no. 1-2, pp. 17-22, 2011.

[20] M. Miyake, T. Hiramatsu, and M. Maeda, "Removal of phosphorus and antimony in silicon by electron beam melting at low vacuum," Journal of the Japan Institute of Metals, vol. 70, no. 1, pp. 43-46, 2006.

[21] K. Hickman, "Reviewing the evaporation coefficient," Desalination, vol. 1, no. 1, pp. 13-29, 1966.

[22] K. Hanazawa, N. Yuge, S. Hiwasa, and Y. Kato, "Evaporation of phosphorus in molten silicon with electron beam irradiation method," Journal of the Japan Institute of Metals, vol. 67, no. 10, pp. 569-574, 2003.

[23] K. Hanazawa, N. Yuge, and Y. Kato, "Evaporation of phosphorus in molten silicon by an electron beam irradiation method," Materials Transactions, vol. 45, no. 3, pp. 844-849, 2004.

[24] J. C. S. Pires, A. F. B. Braga, and P. R. Mei, "Profile of impurities in polycrystalline silicon samples purified in an electron beam melting furnace," Solar Energy Materials and Solar Cells, vol. 79, no. 3, pp. 347-355, 2003.

[25] J. C. S. Pires, J. Otubo, A. F. B. Braga, and P. R. Mei, “The purification of metallurgical grade silicon by electron beam melting," Journal of Materials Processing Technology, vol. 169, no. 1, pp. 16-20, 2005.

[26] D. Luo, N. Liu, Y. Lu, G. Zhang, and T. Li, "Removal of impurities from metallurgical grade silicon by electron beam melting," Journal of Semiconductors, vol. 32, no. 3, Article ID 033003, 2011.

[27] D. Jiang, Y. Tan, S. Shi, W. Dong, Z. Gu, and R. Zou, "Removal of phosphorus in molten silicon by electron beam candle melting," Materials Letters, vol. 78, pp. 4-7, 2012.

[28] P. R. Mei, S. P. Moreira, E. Cardoso, A. D. S. Côrtes, and F. C. Marques, "Purification of metallurgical silicon by horizontal zone melting," Solar Energy Materials and Solar Cells, vol. 98, pp. 233-239, 2012.

[29] T. Liu, Z. Dong, Y. Zhao et al., "Large scale purification of metallurgical silicon for solar cell by using electron beam melting," Journal of Crystal Growth, vol. 351, no. 1, pp. 19-22, 2012.

[30] Y. Tan, X. Guo, S. Shi, W. Dong, and D. Jiang, "Study on the removal process of phosphorus from silicon by electron beam melting," Vacuum, vol. 93, pp. 65-70, 2013.

[31] S. Shi, W. Dong, X. Peng, D. Jiang, and Y. Tan, "Evaporation and removal mechanism of phosphorus from the surface of silicon melt during electron beam melting," Applied Surface Science, vol. 266, pp. 344-349, 2013.

[32] S. Choi, B. Jang, J. Lee, Y. Ahn, W. Yoon, and J. Joo, "Effects of electron beam patterns on melting and refining of silicon for photovoltaic applications," Renewable Energy, vol. 54, pp. 4045, 2013.

[33] K. Suzuki, K. Sakaguchi, T. Nakagiri, and N. Sano, "Gaseous removal of phosphorus and boron from molten silicon," Journal of the Japan Institute of Metals, vol. 54, no. 2, pp. 161-167, 1990.

[34] N. Yuge, K. Hanazawa, K. Nishikawa, and H. Terashima, "Removal of phosphorus, aluminum and calcium by evaporation in molten silicon," Journal of the Japan Institute of Metals, vol. 61, no. 10, pp. 1086-1093, 1997.
[35] S. Zheng, W. Chen, J. Cai, J. Li, C. Chen, and X. Luo, "Mass transfer of phosphorus in silicon melts under vacuum induction refining," Metallurgical and Materials Transactions B, vol. 41, no. 6, pp. 1268-1273, 2010.

[36] S. Zheng, T. Abel Engh, M. Tangstad, and X. Luo, "Separation of Phosphorus from silicon by induction vacuum refining," Separation and Purification Technology, vol. 82, no. 1, pp. 128137, 2011.

[37] S. Zheng, J. Safarian, S. Seok, S. Kim, T. Merete, and X. Luo, "Elimination of phosphorus vaporizing from molten silicon at finite reduced pressure," Transactions of Nonferrous Metals Society of China, vol. 21, no. 3, pp. 697-702, 2011.

[38] J. Safarian and M. Tangstad, "Kinetics and mechanism of phosphorus removal from silicon in vacuum induction refining," High Temperature Materials and Processes, vol. 31, no. 1, pp. 7381, 2012.

[39] J. Safarian and M. Tangstad, "Vacuum refining of molten silicon," Metallurgical and Materials Transactions B, vol. 43, no. 6, pp. 1427-1445, 2012.

[40] X. M. Xue, H. G. Jiang, Z. T. Sui, B. Z. Ding, and Z. Q. Hu, "Influence of phosphorus addition on the surface tension of liquid iron and segregation of phosphorus on the surface of FeP alloy," Metallurgical and Materials Transactions B, vol. 27, no. 1, pp. 71-79, 1996.

[41] X. Peng, W. Dong, Y. Tan, and D. Jiang, "Removal of aluminum from metallurgical grade silicon using electron beam melting," Vacuum, vol. 86, no. 4, pp. 471-475, 2011.

[42] J. Sun, J. Zhang, H. Wang et al., "Purification of metallurgical grade silicon in an electron beam melting furnace," Surface \& Coating Technology, vol. 228, supplement 1, pp. S67-S71, 2013.

[43] D. Jiang, Y. Tan, S. Shi, W. Dong, Z. Gu, and X. Guo, "Evaporated metal aluminium and calcium removal from directionally solidified silicon for solar cell by electron beam candle melting," Vacuum, vol. 86, no. 10, pp. 1417-1422, 2012.

[44] M. D. Johnston and M. Barati, "Distribution of impurity elements in slag-silicon equilibria for oxidative refining of metallurgical silicon for solar cell applications," Solar Energy Materials and Solar Cells, vol. 94, no. 12, pp. 2085-2090, 2010.

[45] M. D. Johnston and M. Barati, "Effect of slag basicity and oxygen potential on the distribution of boron and phosphorus between slag and silicon," Journal of Non-Crystalline Solids, vol. 357, no. 3, pp. 970-975, 2011.

[46] J. Wu, W. Ma, Y. Li, B. Yang, D. Liu, and Y. Dai, "Thermodynamic behavior and morphology of impurities in metallurgical grade silicon in process of $\mathrm{O}_{2}$ blowing," Transactions of Nonferrous Metals Society of China, vol. 23, no. 1, pp. 260-265, 2013.

[47] T. Yoshikawa and K. Morita, "Refining of silicon during its solidification from a Si-Al melt," Journal of Crystal Growth, vol. 311, no. 3, pp. 776-779, 2009. 

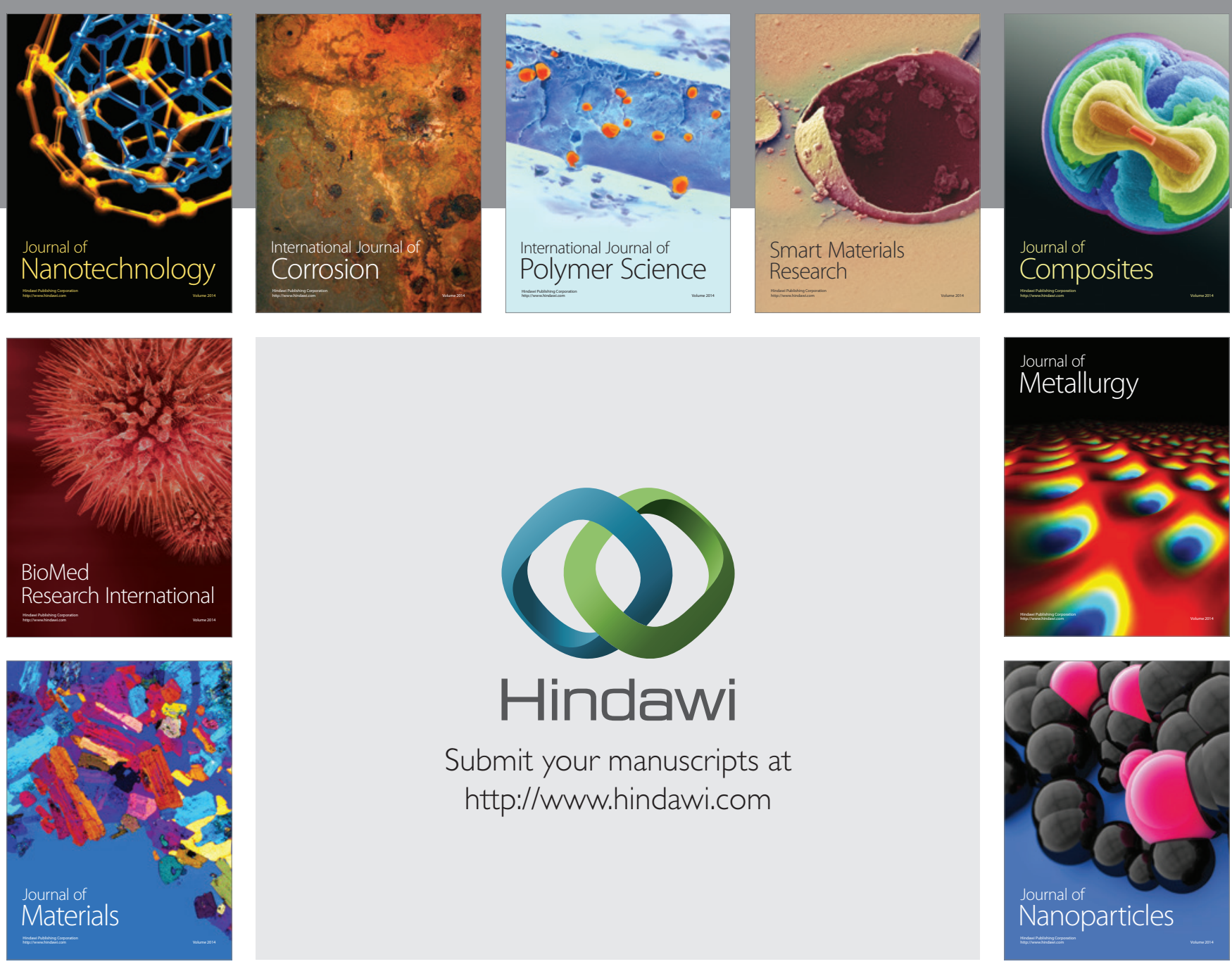

Submit your manuscripts at http://www.hindawi.com
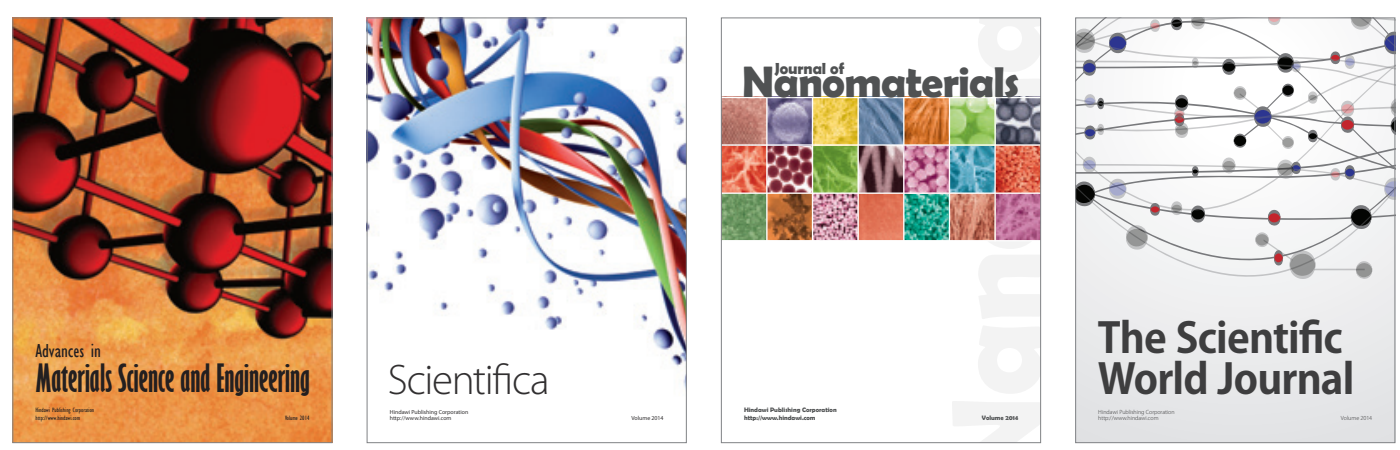

\section{The Scientific World Journal}
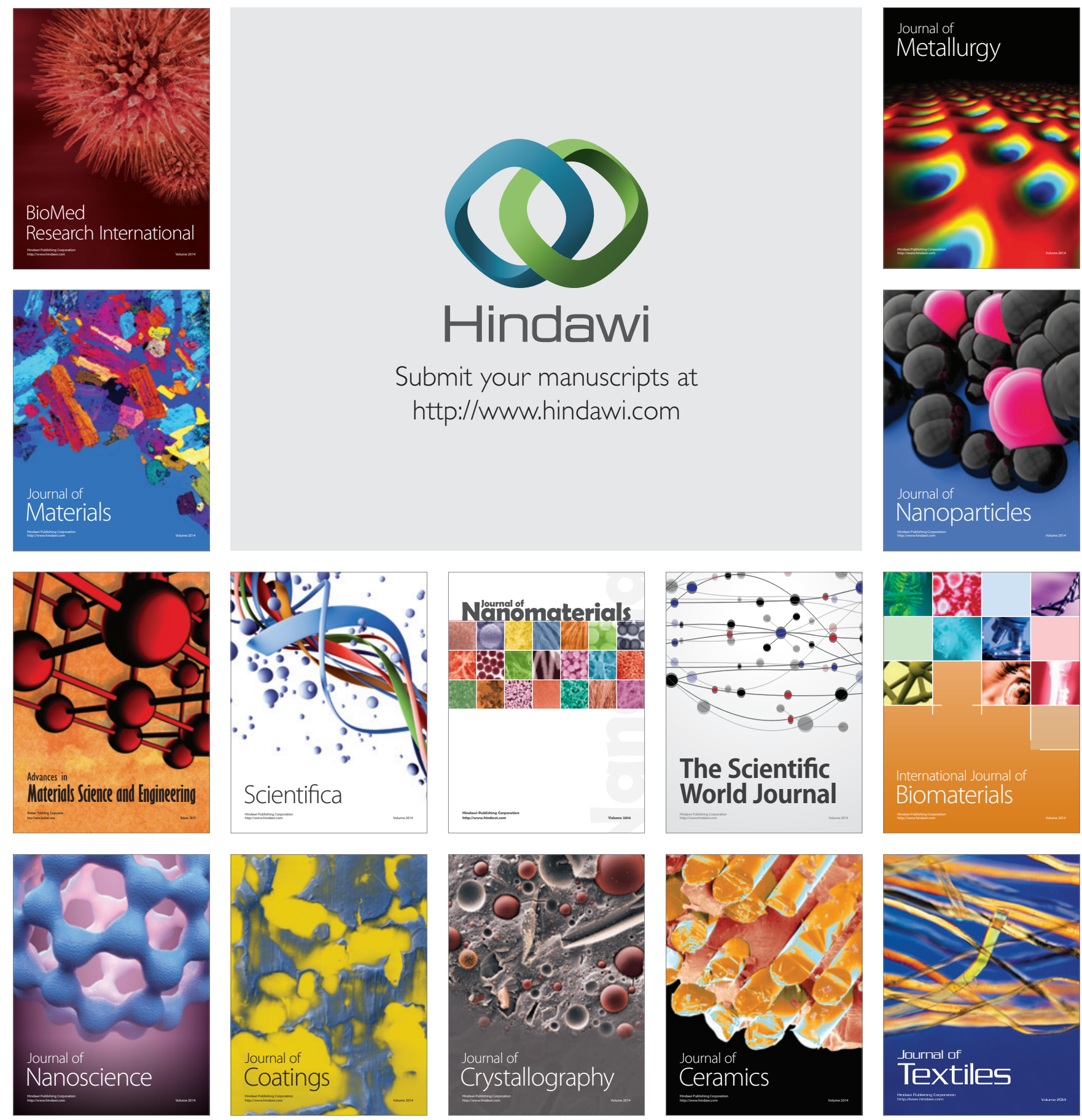